Mineralogy and Petrology (1993) 47: 149-169

\section{Mineralogy and Petrology}

(C) Springer-Verlag 1993 Printed in Austria

\title{
Primitive Island Arc and Oceanic Lavas from the Hunter Ridge-Hunter Fracture Zone. Evidence from Glass, Olivine and Spinel Compositions
}

\author{
I. A. Sigurdsson ${ }^{1}$, V. S. Kamenetsky ${ }^{1,3}$, A. J. Crawford ${ }^{1}$, S. M. Eggins ${ }^{2}$, and \\ S. K. Zlobin ${ }^{3}$ \\ ${ }^{1}$ Department of Geology, University of Tasmania, GPO Box 252c, Hobart, Tasmania \\ 7001, Australia \\ ${ }^{2}$ Research School of Earth Sciences, Australian National University, GPO Box 4, \\ Canberra 2601, Australia, \\ ${ }^{3}$ Vernadsky Institute of Geochemistry, Russian Academy of Sciences, Moscow 117975, \\ Russia
}

With 5 Figures

Received June 24, 1992

Accepted October 18, 1992

\section{Summary}

At its southernmost end, the main spreading centre of the North Fiji Basin is propagating into arc crust of the poorly-known Hunter Ridge. We define nine magmatic groups from major element glass chemistry and olivine and spinel compositions in samples dredged from twenty six sites in this area by the "R/V Academician A. Nesmeyanov" in 1990. These include groups of boninites, island arc tholeiites (IAT), mid-ocean ridge basalts (MORB), enriched mid-ocean ridge basalts (E-MORB), olivine porphyritic andesites and basaltic andesite and Na-rhyolites. Primitive lavas containing highly forsteritic olivine phenocrysts are common in all the groups, except for the rhyolites.

We report over 100 glass analyses for dredged rocks from this region, and about 300 olivine-spinel pairs for representatives of all the magmatic groups identified, except the Na-rhyolites.

The MORB in this region are probably produced at the propagating spreading centre in the southern part of the North Fiji Basin. Juxtaposition of shallow, hot MORB-source diapirs supplying the MORB in this area, and the sub-arc damp, refractory upper mantle beneath the Hunter Ridge, provides suitable petrogenetic conditions to produce a range of magma types, from island arc tholeiites through to high-Ca boninites. The latter were recovered in eleven dredges.

The E-MORB lavas recovered from the extreme southern margin of the North Fiji Basin are shown to be essentially identical to those dredged from adjacent older South Fiji Basin crust. It is hypothesized that the former were either scraped off the South Fiji 
Basin crust during an episode of oblique subduction that may have generated the Hunter Ridge during the last $5 \mathrm{Myr}$, or alternatively, that slices of the South Fiji Basin crust were trapped and incorporated into the North Fiji Basin as the subduction zones fronting the Vanuatu arc stepped or propagated southward.

\section{Zusammenfassung}

Primitive Inselbogen- und ozeanische Laven von Hunter Rücken und der Hunter BruchZone: die Bedeutung der Zusammensetzung von Glas, Olivin und Spinell.

Das spreading centre des Nord-Fidschi-Beckens setzt sich an seinem südlichsten Ende in die Inselbogen-Kruste des noch wenig bekannten Hunter-Rückens fort.

Wir definieren 9 magmatische Gruppen auf der Basis der Hauptelement-Zusammensetzung von Gläsern und der Zusammensetzung von Olivin und Spinell in Proben die das Forschungsschiff R/V Akademiker A. Nesmeyanov von 26 Stellen im Jahr 1990 aufgesammelt hat. $\mathrm{Zu}$ diesen gehören Gruppen von Boniniten, Inselbogentholeiiten (IAT), Basalten zentralozeanischer Rücken (MORB), angereicherte zentralozeanische Rücken (E-MORB), Olivin-porphyritische Andesite und basaltische Andesite, sowie Na-Rhyolite. Primitive Laven mit Olivinkristallen, die reich an Forsterit-Komponenten sind, kommen in allen diesen Gruppen, mit Ausnahme der Rhyolite, vor.

Wir legen über 100 Glas-Analysen von Gesteinen aus diesem Gebiet vor und über 300 Olivin-Spinell-Paare für Vertreter aller der hier identifizierten magmatischen Gruppen, mit Ausnahme der Natriumrhyolite.

Die MORB in diesem Gebiet sind wahrscheinlich an dem aktiven Spreading Center im Südteil des Nord-Fidschi-Beckens entstanden. Das nebeneinander Vorkommen von seichten heißen MORB-Quellen Diapiren, die MORB in diesem Gebiet erzeugen, und der Sub-Inselbogen, wasserhaltige, refraktäre obere Mantel unter dem Hunter Rücken führen $\mathrm{zu}$ geeigneten petrogenetischen Bedingungen für die Entstehung einer Vielfalt von Magmatypen, von Inselbogentholeiiten bis zu sehr Kalziumreichen Boniniten. Die letzteren wurden in 11 Dredge-Proben gefunden.

Die E-MORB Laven, die aus dem extremen Südteil des Nord-Fidschi-Beckens entnommen wurden, sind im wesentlichen mit jenen identisch, die aus der benachbarten älteren Kruste des Süd-Fidschi-Beckens stammen. Es wird vermutet, daß die letzteren entweder aus dem Süd-Fidschi-Becken während einer Episode obliger Subduktion, die in den letzten 5 Millionen Jahren zur Entstehung des Hunter Ridge geführt hat, abgeschert wurden, oder auch daß Teile der Kruste des Süd-Fidschi-Beckens in das Nord-Fidschi-Becken inkorporiert wurden als Subduktionszonen gegenüber dem Vanuato-Bogen sich nach Süden fortbewegten.

\section{Introduction and Geological Setting}

In 1990, the Soviet research vessel "Academician A. Nesmeyanov" dredged the southernmost part of the North Fiji Basin (NFB). The diverse assemblage of rocks recovered includes several suites of primitive arc tholeiites, boninites, mid-ocean ridge basalts, and sodic rhyolites plus a variety of peridotites. This remarkable diversity of lithologies reflects the complex tectonic setting of the dredged area. In this paper, we describe nine different magmatic groups recognized from major element compositions of 104 fresh volcanic glasses (occurring either as pillow rims or as glass fragments in hyaloclastites) from 26 dredge stations. We also report 


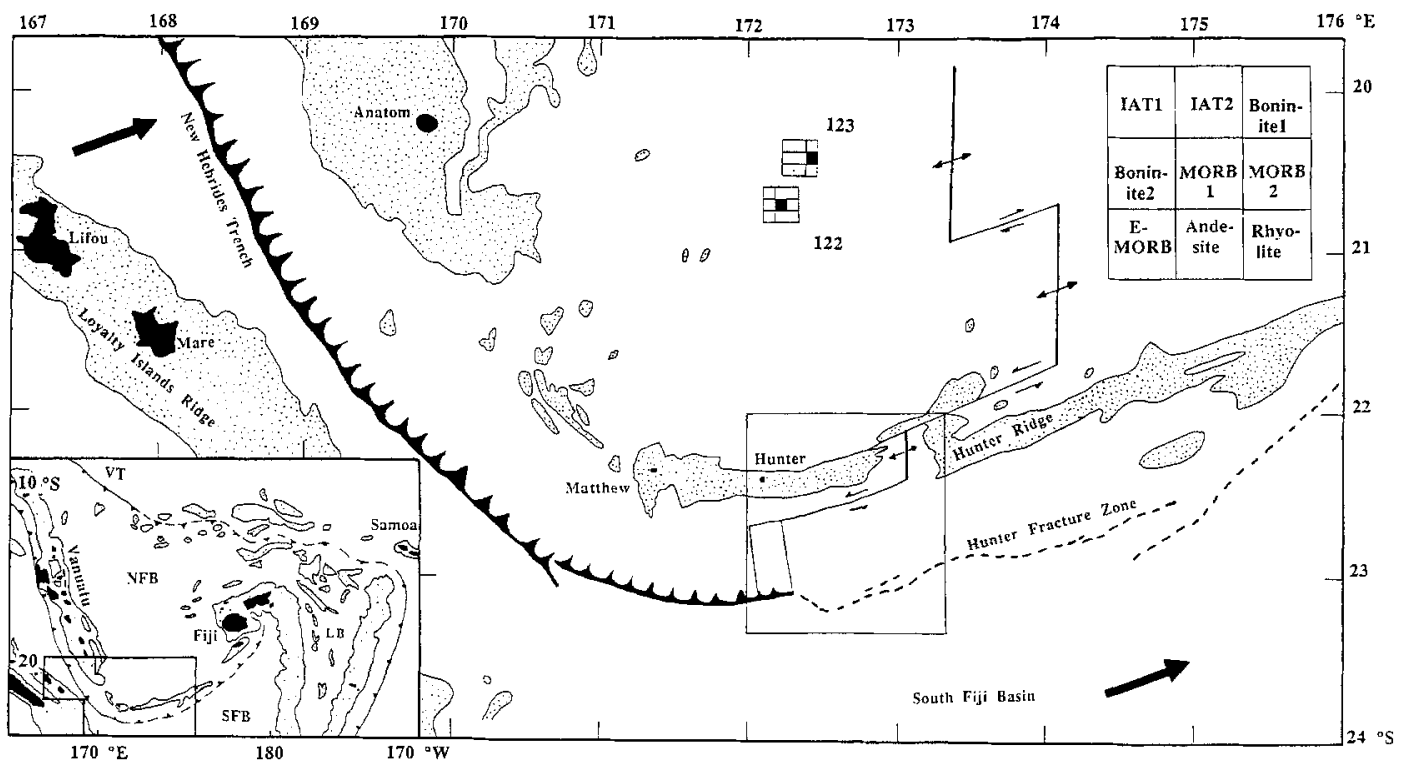

a

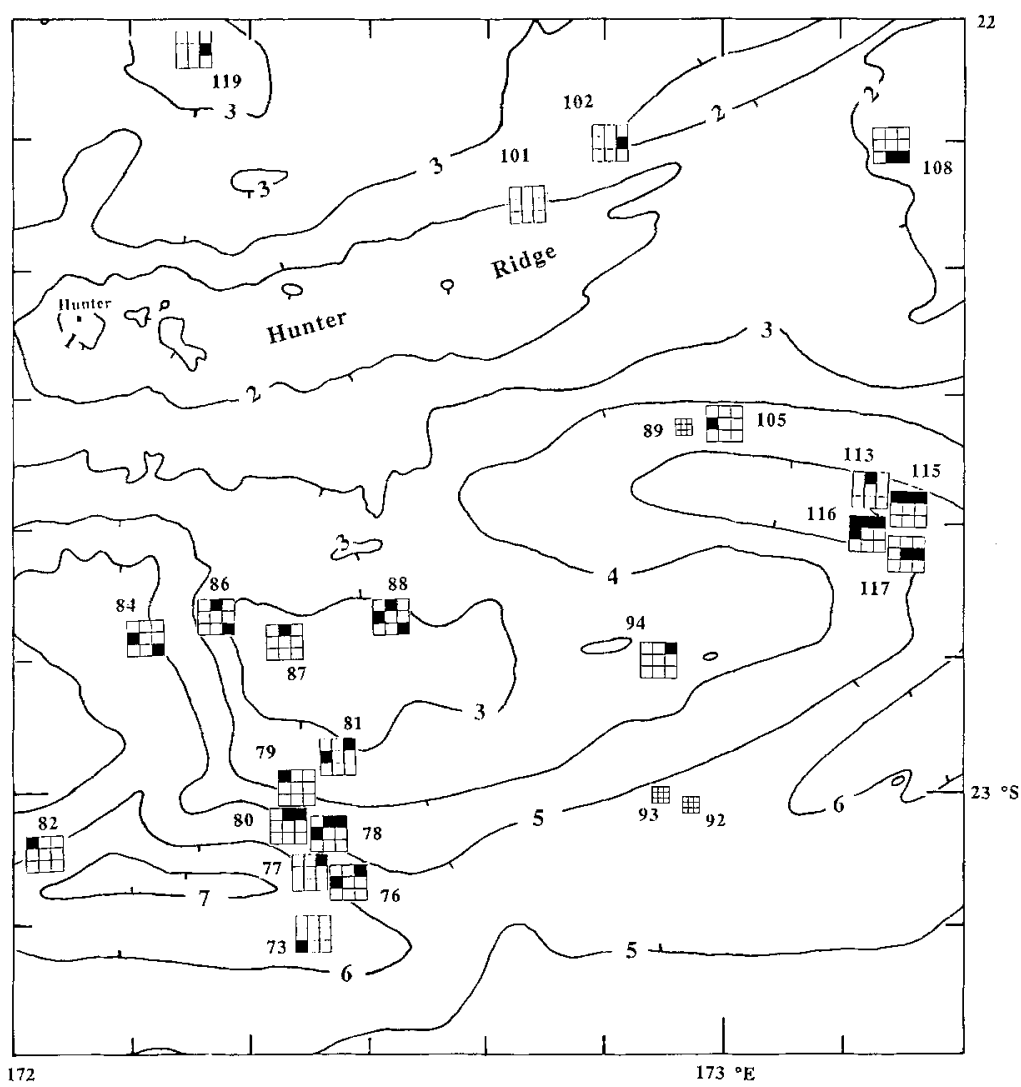

b

Fig. 1. Location map of the North Fiji Basin. a. Tectonic configuration and location of dredges 122 and 123. Filled boxes indicate magma groups recognized from glass compositions (see key in the top righthand corner). Stippled area shows water depth between 0 $2000 \mathrm{~m}$. NFB = North Fiji Basin, SFB = South Fiji Basin, LB = Lau Basin, VT = Vityaz Trench, b. Bathymetric map of the dredged area, showing locations of dredge stations and magma groups. Smaller boxes indicate that no glasses were present in samples from that station. Both maps are redrawn from maps by Maillet et al. (1989) 
olivine and olivine-spinel pair compositions of selected samples from the main magmatic groups identified.

The geological setting and the evolution of the NFB is more fully described elsewhere (e.g., Dubois et al., 1977; Dupuy et al., 1982; Monzier et al., 1984; Hamburger and Isacks, 1987; Auzende et al., 1988a, b; Maillet et al., 1989). It is an active, roughly triangular back arc basin located between the Pacific and India-Australian plates; it is bounded to the north by the inactive Vityaz trench, by the Vanuatu arc in the west and the Hunter Ridge-Hunter Fracture Zone (HFZ) and Fiji in the south and east respectively (Fig. 1a). The basin is tectonically complex and unstable, and formed during the last 8-10 Myr (Auzende et al., 1988a, b). Currently, the IndiaAustralian plate is subducting under the NFB in a $70^{\circ} \mathrm{E}$ convergence direction. South of $23^{\circ} \mathrm{S}$ subduction becomes more oblique, eventually shifting to inferred transform fault motion along the HFZ, which extends northeastwards to Fiji (Fig. 1a).

The area sampled for this study lies at the southern margin of the NFB, east of Matthew and Hunter Islands, and overlapping the Hunter Ridge in the area where it abuts the southern end of the NFB main spreading ridge (Fig. 1a). Within the $\mathrm{NFB}$, fossil transform faults aligned $45^{\circ} \mathrm{E}$, and magnetic anomalies oriented $135^{\circ} \mathrm{E}$, are believed to be linked to a NW-SE-trending spreading ridge that was active before the presently active ridge came into existence about $3 \mathrm{Ma}$ (Maillet et al., 1989). Since then, the subduction zone has propagated southward from Anatom Island towards the Hunter Ridge. This propagation may partly explain why the volcanic arc is more poorly defined south of Anatom, and why the depth of the subducted slab is $300 \mathrm{~km}$ north of Anatom Island, the southernmost island in the Vanuatu arc, and only $200 \mathrm{~km}$ further south than Anatom (Maillet et al., 1989; Monzier et al., submitted).

Maillet et al.(1989) produced a new bathymetric map, and described the regional structure and geodynamic development of this area. They suggested that the NFB spreading ridge in this region is propagating southward into the Hunter Ridge (Fig. 1a), and that a small pull-apart basin may be developing south of the Hunter Ridge, linked to the spreading ridge that is presently transecting the Hunter Ridge by an ENE-trending transform fault zone (Fig. 1a).

Published geochemical work on samples from the NFB focuses mainly on near zero-age basalts from the spreading ridges in the central and northern part of the basin (Auzende et al., 1988a; Price et al., 1990; Johnson and Sinton, 1990; Sinton et al., 1991; Eissen et al., 1991). The Hunter Ridge appears subaerially at its SW end as Matthew and Hunter Islands (Maillet et al., 1986), which are active volcanoes with andesitic lavas showing anomalously low $\mathrm{TiO}_{2}$ contents $(0.37 \%$ at $5 \% \mathrm{MgO}$ on Hunter Island), and bearing cognate doleritic xenoliths (Maillet et al., 1986). Nothing is known of the petrology and composition of the Hunter Ridge over the more than $1000 \mathrm{~km}$-long segment extending NE from Hunter Island, to its termination in Fijian waters between Kandavu Island and the northern Lau Islands.

\section{Dredge Locations and Analytical Methods}

Locations of the 26 dredge stations from which volcanic rocks were recovered during the "R/V Academican A. Nesmeyanov" cruise are shown in Fig. 1 and listed in 
Table 1. Location of dredge stations and magma groups identified from glass compositions

\begin{tabular}{|c|c|c|c|c|}
\hline Dredge no. & Latitude & Longitude & Water depth, m & Magma groups \\
\hline$N 17.73$ & $23^{\circ} 10^{\prime}$ & $172^{\circ} 26^{\prime}$ & $6500-6120$ & Enriched mid ocean ridge basalt \\
\hline$N 17-76$ & $23^{\circ} 06^{\prime}$ & $172^{\circ} 28^{\prime}$ & $6280-6200$ & Boninite $1 / 2$ \\
\hline$N 17-77$ & $23^{\circ} 05^{\prime}$ & $172^{\circ} 26^{\prime}$ & $5960-5840$ & Boninite 1 \\
\hline$N 17-78$ & $23^{\circ} 04^{\prime}$ & $172^{\circ} 26^{\prime}$ & $5280-4650$ & Island arc tholeitie 2 , boninite $1 / 2$ \\
\hline$N 17.79$ & $23^{\circ} 01^{\prime}$ & $172^{\circ} 24^{\prime}$ & $4650-4400$ & Island arc tholeite 1 \\
\hline$N 17-80$ & $23^{\circ} 02^{\prime}$ & $172^{\circ} 24^{\prime}$ & $4400-4250$ & island arc tholeiite 2 , boninite 1 \\
\hline$N 17-81$ & $22^{\circ} 58^{\prime}$ & $172^{\circ} 27^{\prime}$ & $3480-3040$ & Boninite $1 / 2$ \\
\hline N17.82 & $23^{\circ} 05^{\prime}$ & $172^{\circ} 02^{\prime}$ & $6920-6840$ & Island arc tholeiite 1 \\
\hline N17.84 & $22^{\circ} 48^{\prime}$ & $172^{\circ} 12^{\prime}$ & $5200 \cdot 4700$ & Boninite 2 , rhyolite \\
\hline$N 17.86$ & $22^{\circ} 47^{\prime}$ & $172^{\circ} 18^{\circ}$ & $3160-2900$ & Island arc tholeiite 2 , rhyolite \\
\hline$N+7-87$ & $22^{\circ} 48^{\prime}$ & $172^{\circ} 24^{\prime}$ & $2630-2260$ & Island arc tholeiite 2 \\
\hline$N 17-88$ & $22^{\circ} 46^{\prime}$ & $172^{\circ} 32^{\prime}$ & $2600-2360$ & Island arc tholeiite 2 , boninite 2 , rhyolite. \\
\hline N17-89 & $22^{\circ} 32^{\prime}$ & $172^{\circ} 54^{\prime}$ & $4300-4240$ & No glass present \\
\hline N17-92 & $23^{\circ} 01^{\prime}$ & $172^{\circ} 54^{\prime}$ & $600-5600$ & No glass present \\
\hline N $17-93$ & $23^{\circ} 00^{\prime}$ & $172^{\circ} 50^{\prime}$ & $5220-4900$ & No glass present \\
\hline$N 17-94^{*}$ & $22^{\circ} 46^{\prime}$ & $172^{\circ} 50^{\prime}$ & 3360 & Boninite 1 \\
\hline N17-101* & $22^{\circ} 15^{\prime}$ & $172^{\circ} 45^{\prime}$ & 2000 & Basaltic andesite \\
\hline N17-102 & $22^{\circ} 11^{\prime}$ & $172^{\circ} 51^{\prime}$ & $1940-1840$ & Mid ocean ridge basalt 2 \\
\hline$N 17-105$ & $22^{\circ} 32^{\prime}$ & $172^{\circ} 59^{\prime}$ & $4620-4040$ & Boninite 2 \\
\hline N17-108 & $22^{\circ} 10^{\prime}$ & $173^{\circ} 13^{\prime}$ & $1520-1320$ & Andesite, rhyolite \\
\hline$N 17-113$ & $22^{\circ} 37^{\prime}$ & $173^{\circ} 13^{\prime}$ & $5560-5160$ & Island arc tholeiite 2 \\
\hline N17.115 & $22^{\circ} 39^{\prime}$ & $173^{\circ} 13^{\prime}$ & $5880-5560$ & Island arc tholeiite $1 / 2$, boninite 1 \\
\hline$N 17-116$ & $22^{\circ} 41^{\prime}$ & $173^{\circ} 13^{\prime}$ & $5400-500$ & Island arc tholeite $1 / 2$, boninite $1 / 2$ \\
\hline N17-117 & $22^{\circ} 42^{\prime}$ & $173^{\circ} 13^{\prime}$ & $4800-4480$ & Mid ocean ridge basalt $1 / 2$ \\
\hline N17-119* & $22^{\circ} 03^{\prime}$ & $172^{\circ} 54^{\prime}$ & 1960 & Mid ocean ridge basalt 2 \\
\hline$N 17-122$ & $20^{\circ} 31^{\prime}$ & $172^{\circ} 14^{\prime}$ & $3400-3200$ & Mid ocean ridge basalt 1 \\
\hline $\begin{array}{l}\text { N17-123 } \\
\text { * Gravity co }\end{array}$ & $20^{\circ} 29^{\prime}$ & $172^{\circ} 15^{\prime}$ & $2800-2620$ & Mid ocean ridge basalt 2 \\
\hline
\end{tabular}

Table 1. All samples were examined under a binocular microscope, and fresh glass, where present, was handpicked and prepared for major element analyses using the electron microprobe. Most of the glasses contain some quenched crystals, but these were easily avoided during microprobe analyses. Each reported glass composition consists of an average of at least three points.

Selected samples were crushed by hand with pestle and mortar, sieved, and olivine crystals picked from the size fractions between 0.3 and $1.0 \mathrm{~mm}$. Approximately 250 olivine grains from each sample were glued in epoxy and polished for microprobe analyses. Olivine-spinel pairs were analysed wherever spinel inclusions were exposed on the polished surface. Only $\mathrm{SiO}_{2}, \mathrm{MgO}, \mathrm{FeO}$ and $\mathrm{CaO}$ were analysed in olivine. Most microprobe analyses used a fully automated three spectrometer Cameca SX50 electron microprobe (University of Tasmania) calibrated with natural mineral standards (PAP data reduction). Olivine (USNM 111312/444), basaltic glass VG-2 (USNM 111240/52) (Jarosewich et al., 1980) and spinel UV-126 (Lavrentev et al., 1974) were used as secondary standards. Analytical conditions were $15 \mathrm{kV}$ accelerating voltage and $20 \mathrm{nA}$ beam current. Significant $\mathrm{Na}$-loss was detected in the rhyolitic glasses at these conditions but was minimized by using slightly defocussed beam and $8 \mathrm{nA}$ beam current. Analyses of natural obsidian glass (Astimex Scientific Limited) and Soda-Lime Flat Glass (National Bureau of Standards, Standard Reference Material 620) showed Na-loss to be less than 3\% relative using these conditions.

Some olivine and spinel in samples $92 / 37$ and $115 / 3$ were analysed on a four spectrometer Camebax MicroBeam microprobe at Vernadsky Institute of Geochemistry, Moscow. 

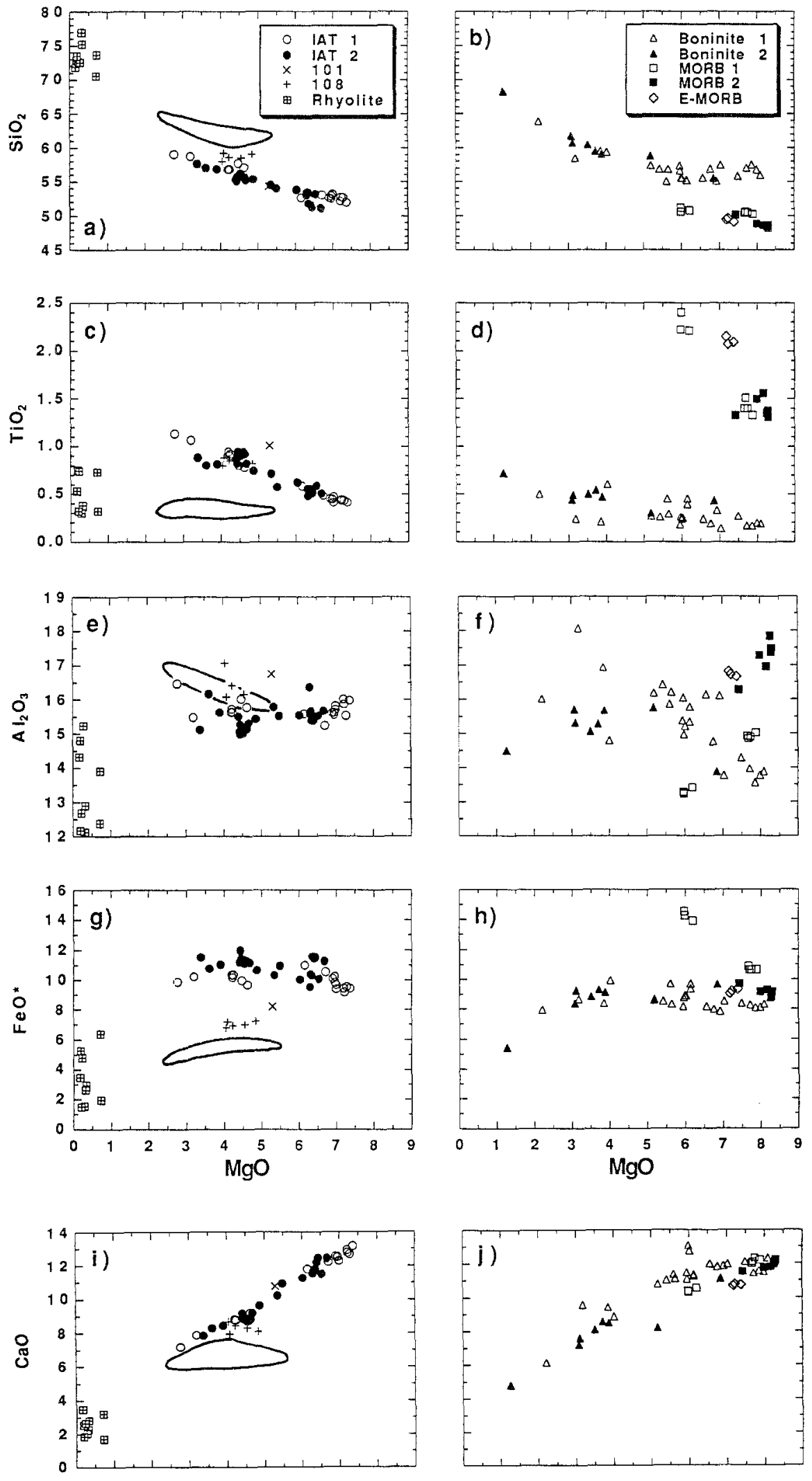

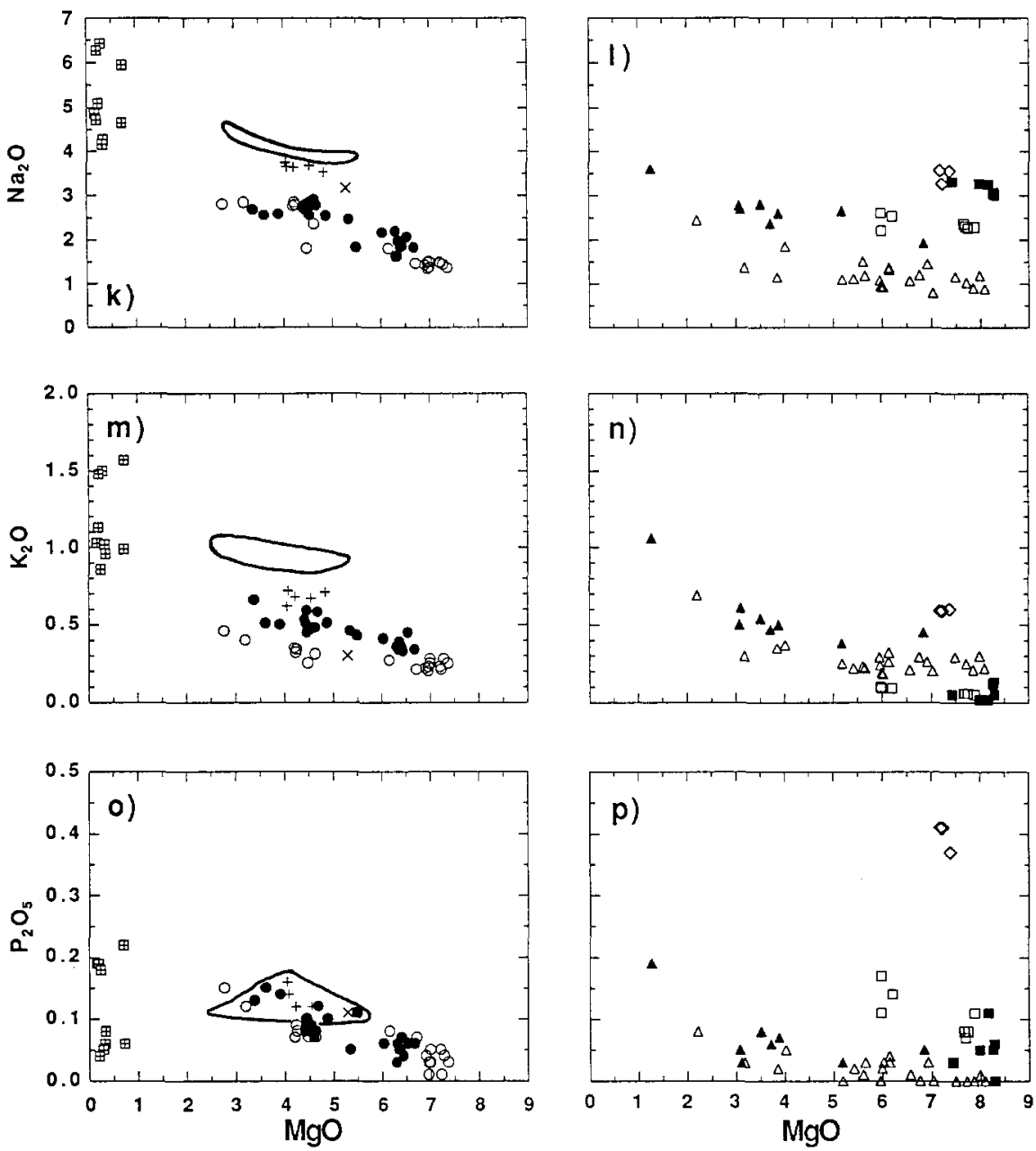

Fig. 2. MgO variation diagrams for the NFB-glasses: all elements are in $\mathrm{wt}_{\mathrm{t}}^{\mathrm{o}}$. Also shown is the field for wholerock compositions of Matthew and Hunter andesites (Maillet et al., 1986)

\section{Major Element Geochemistry}

Based on major elements, we divide the glasses into nine groups (Fig. 2). These include two groups of island arc tholeiites, two groups of boninites, two groups of mid-ocean ridge basalts, one of enriched mid-ocean ridge basalt, one of sodic rhyolites and one group of basaltic andesites and andesites. Analyses of representative samples from each group are given in Table 2.

\section{Island Arc Tholeiites (IAT1 and IAT2)}

Forty-two glasses from ten dredge stations are island arc tholeiites (Jakes and Gill, 1970; Miyashiro,1974). $\mathrm{MgO}$ contents range from 7.4-2.8\% with $\mathrm{SiO}_{2}$ content from $51-59 \% . \mathrm{TiO}_{2}$ increases significantly with fractionation from $0.4-1.1 \%$ and $\mathrm{K}_{2} \mathrm{O}$ from $0.2-0.6 \%$ whereas $\mathrm{Al}_{2} \mathrm{O}_{3}$ is almost constant at $15.0-16.5 \%$. FeO* shows a small increase with fractionation. The distinction between the two arc tholeiite groups is 
Table 2. Microprobe glass analyses of representative samples

\begin{tabular}{|c|c|c|c|c|c|c|c|c|c|}
\hline Group & Island are & tholeiite & 1 & Island are & tholeilte & 2 & Boninite 1 & & \\
\hline Sample & $79 / 9$ & $79 / 20$ & $115 / 4$ & $78 / 64$ & $87 / 7$ & $113 / 8$ & $81 / 18$ & $76 / 35$ & $78 / 66$ \\
\hline $\mathrm{SlO}_{2}$ & 57.23 & 56.12 & 51.23 & 56.68 & 55.07 & 52.41 & 57.32 & 56.09 & 55.83 \\
\hline $\mathrm{TiO}_{2}$ & 1.09 & 0.89 & 0.42 & 0.80 & 0.93 & 0.57 & 0.23 & 0.17 & 0.19 \\
\hline $\mathrm{Al}_{2} \mathrm{O}_{3}$ & 15.96 & 15.52 & 15.74 & 16.08 & 14.81 & 15.32 & 17.72 & 15.03 & 13.85 \\
\hline $\mathrm{FeO}$ " & 9.56 & 10.01 & 9.25 & 10.70 & 11.26 & 9.93 & 8.51 & 8.00 & 8.30 \\
\hline Mno & 0.15 & 0.14 & 0.17 & 0.16 & 0.21 & 0.18 & 0.10 & 0.13 & 0.08 \\
\hline $\mathrm{MgO}$ & 2.69 & 4.18 & 7.09 & 3.60 & 4.39 & 6.46 & 3.12 & 5.82 & 8.07 \\
\hline $\mathrm{CaO}$ & 6.98 & 8.66 & 12.69 & 8.26 & 8.88 & 11.34 & 9.39 & 11.22 & 12.30 \\
\hline $\mathrm{Na}_{2} \mathrm{O}$ & 2.71 & 2.81 & 1.47 & 2.55 & 2.68 & 2.03 & 1.34 & 1.06 & 0.88 \\
\hline $\mathrm{K}_{2} \mathrm{O}$ & 0.45 & 0.32 & 0.22 & 0.51 & 0.44 & 0.44 & 0.29 & 0.28 & 0.22 \\
\hline $\mathrm{P}_{2} \mathrm{O}_{5}$ & 0.14 & 0.09 & 0.05 & 0.15 & 0.09 & 0.06 & 0.03 & 0.00 & 0.00 \\
\hline Total & 96.96 & 98.74 & 98.33 & 99.49 & 98.76 & 98.75 & 98.06 & 97.81 & 99.73 \\
\hline $\mathrm{mg} \#$ & 33.4 & 42.7 & 57.7 & 37.5 & 41.0 & 53.7 & 39.5 & 56.5 & 63.4 \\
\hline Group & Boninite 2 & & & MORB 1 & & & MOAB 2 & & \\
\hline Sample & $88 / 14$ & $76 / 39$ & $105 / 1$ & $197 / 16$ & $122 / 11$ & $117 / 4$ & $117 / 5$ & $117 / 2$ & $123 / 1$ \\
\hline $\mathrm{SiO}_{2}$ & 68.87 & 59.72 & 54.82 & 50.44 & 50.53. & 50.25 & 48.76 & 48.76 & 48.69 \\
\hline $\mathrm{TiO}_{2}$ & 0.73 & 0.49 & 0.42 & 2.36 & 1.40 & 1.33 & 1.50 & 1.56 & 1.38 \\
\hline $\mathrm{Al}_{2} \mathrm{O}_{3}$ & 14.61 & 14.87 & 13.71 & 13.05 & 14.91 & 15.03 & 17.25 & 17.00 & 17.37 \\
\hline $\mathrm{FeO}$ & 5.48 & 8.74 & 9.55 & 14.06 & 10.65 & 10.67 & 9.15 & 9.32 & 8.83 \\
\hline Mno & 0.14 & 0.10 & 0.18 & 0.18 & 0.11 & 0.19 & 0.10 & 0.19 & 0.12 \\
\hline MgO & 1.28 & 3.46 & 6.76 & 5.90 & 7.75 & 7.88 & 7.98 & 8.18 & 8.29 \\
\hline $\mathrm{CaO}$ & 4.84 & 8.00 & 10.99 & 10.19 & 12.33 & 12.22 & 11.74 & 11.86 & 12.13 \\
\hline $\mathrm{Na}_{2} \mathrm{O}$ & 3.63 & 2.76 & 9.90 & 2.17 & 2.26 & 2.29 & 3.26 & 3.26 & 3.07 \\
\hline $\mathrm{K}_{2} \mathrm{O}$ & 1.07 & 0.54 & 0.44 & 0.09 & 0.06 & 0.05 & 0.02 & 0.02 & 0.13 \\
\hline $\mathrm{P}_{2} \mathrm{O}_{5}$ & 0.19 & 0.08 & 0.05 & 0.17 & 0.08 & 0.11 & 0.05 & 0.11 & 0.06 \\
\hline Total & 100.84 & 98.77 & 98.82 & 98.61 & 100.08 & 100.03 & 99.79 & 100.26 & 100.07 \\
\hline m g \# & 29.4 & 41.4 & 55.8 & 42.8 & 56.5 & 56.8 & 60.8 & 61.0 & 62.6 \\
\hline Group & $101 / 108$ & & & E-MORB & & & Rhyolite & & \\
\hline Sample & $108 / 14$ & $108 / 7$ & $101 / 1$ & $73 / 8$ & $73 / 2$ & $73 / 1$ & $108 / 1$ & $84 / 11$ & $86 / 9$ \\
\hline $\mathrm{SiO}_{2}$ & 58.42 & 58.11 & 53.14 & 49.19 & 49.51 & 48.63 & 71.76 & 74.42 & 69.84 \\
\hline $\mathrm{TiO}_{2}$ & 0.87 & 0.80 & 0.99 & 2.05 & 2.15 & 2.07 & 0.30 & 0.37 & 0.72 \\
\hline $\mathrm{Al}_{2} \mathrm{O}_{3}$ & 15.86 & 16.04 & 16.40 & 16.57 & 16.83 & 16.50 & 15.08 & 12.76 & 12.25 \\
\hline $\mathrm{FeO}^{*}$ & 7.09 & 6.96 & 8.02 & 9.14 & 9.05 & 9.25 & 1.53 & 2.92 & 6.31 \\
\hline Mno & 0.06 & 0.12 & 0.10 & 0.12 & 0.15 & 0.16 & 0.06 & 0.09 & 0.18 \\
\hline MgO & 4.01 & 4.51 & 5.18 & 7.16 & 7.19 & 7.31 & 0.28 & 0.33 & 0.70 \\
\hline $\mathrm{CaO}$ & 7.87 & 8.29 & 10.55 & 10.68 & 10.69 & 10.63 & 2.02 & 2.80 & 3.18 \\
\hline $\mathrm{Na}_{2} \mathrm{O}$ & 3.60 & 3.65 & 3.10 & 3.23 & 3.56 & 3.52 & 6.36 & 4.22 & 4.60 \\
\hline $\mathrm{K}_{2} \mathrm{O}$ & 0.71 & 0.67 & 0.29 & 0.58 & 0.59 & 0.59 & 1.48 & 0.95 & 0.98 \\
\hline $\mathrm{P}_{2} \mathrm{O}_{5}$ & 0.14 & 0.12 & 0.11 & 0.41 & 0.41 & 0.37 & 0.05 & 0.08 & 0.22 \\
\hline Total & 98.63 & 99.28 & 97.87 & 99.13 & 100.13 & 99.03 & 98.92 & 98.94 & 98.98 \\
\hline $\mathrm{mg} \#$ & 50.2 & 53.6 & 53.5 & 58.3 & 58.6 & 58.5 & 24.6 & 16.8 & 16.5 \\
\hline
\end{tabular}

made on differences in $\mathrm{K}_{2} \mathrm{O}$ content. IAT2 has higher $\mathrm{K}_{2} \mathrm{O}$ contents and also slightly higher $\mathrm{FeO}^{*}$ and lower $\mathrm{SiO}_{2}$ than IAT1 at a given $\mathrm{MgO}$ content (Fig. 2).

\section{Boninites (BON1 and BON2)}

Thirty samples from eleven dredge stations are high-Ca boninites, or derived from a high-Ca boninite parent (Crawford et al., 1989). Compared to the island arc tholeiites, the boninites have higher $\mathrm{SiO}_{2}$ contents and lower $\mathrm{FeO}, \mathrm{TiO}_{2}$ and $\mathrm{P}_{2} \mathrm{O}_{5}$ contents. $\mathrm{MgO}$ contents range from $8.1-1.3 \%$. The boninites are further divided into 
two groups, with $\mathrm{BON} 2$ having significantly higher $\mathrm{Na}_{2} \mathrm{O}$ and slightly higher $\mathrm{SiO}_{2}$, $\mathrm{K}_{2} \mathrm{O}$ and $\mathrm{P}_{2} \mathrm{O}_{5}$ and lower $\mathrm{Al}_{2} \mathrm{O}_{3}$ and $\mathrm{CaO}$ contents than BON1 (Fig. 2).

\section{Mid-Ocean Ridge Basalts (MORB1 and MORB2)}

Thirteen samples from five dredge stations constitute the two groups of mid-ocean ridge basalts (MORB). Four of these dredge stations are located north of the Hunter Ridge but interestingly MORB was also found at station 117 south of the Hunter Ridge in close proximity to island arc tholeiites and boninites. MORB glasses have $8.3-5.9 \% \mathrm{MgO}$, relatively high $\mathrm{TiO}_{2}(>1.2 \%)$ and $\mathrm{Na}_{2} \mathrm{O}(>2 \%)$ contents and low $\mathrm{K}_{2} \mathrm{O}(<0.13 \%)$. MORB2 is distinguished from MORB1 by higher $\mathrm{Al}_{2} \mathrm{O}_{3}$ and $\mathrm{Na}_{2} \mathrm{O}$ and lower $\mathrm{FeO}^{*}$ and $\mathrm{CaO}$ at any $\mathrm{MgO}$ level (Fig. 2). MORB2 is similar, in major element compositions, to "typical" back arc basin basalts (BABB) whereas MORB1 is similar to typical N-MORB from the East Pacific Rise (e.g. Fryer et al., 1981). Our unpublished trace element data show that both groups are slightly enriched over N-MORB in most large ion lithophile elements (LILE).

\section{Enriched Mid-Ocean Ridge Basalts (E-MORB)}

Three glasses from dredge station 73 on the South Fiji Basin (SFB) crust south of the $\mathrm{HFZ}$ are enriched in $\mathrm{TiO}_{2}, \mathrm{Na}_{2} \mathrm{O}, \mathrm{K}_{2} \mathrm{O}$ and $\mathrm{P}_{2} \mathrm{O}_{5}$ compared to all the other groups and resemble E-MORB (Sun and McDonough, 1989). Significantly, our unpublished wholerock data show that similar rocks, lacking glass, also occur at dredge stations 87 and 92 between the Hunter Ridge and HFZ (Fig. 1b). The importance of this distribution of E-MORB-like compositions is discussed in more detail further on.

\section{Basaltic Andesites and Andesites (Stations 101 and 108)}

Six glasses from dredge stations 101 and 108 could not be grouped with other samples and are therefore described separately. Although there are similarities between samples from these two stations, such as high $\mathrm{SiO}_{2}$ and $\mathrm{Na}_{2} \mathrm{O}$, and low FeO* content at a given $\mathrm{MgO}$ content, $\mathrm{K}_{2} \mathrm{O}$ contents are very different (Fig. 2).

Samples from station 108 have $\mathrm{MgO}$ from $4.0-4.8 \%$, whereas sample $101 / 1$ has $5.18 \% \mathrm{MgO}$, and on all major element plots, except $\mathrm{TiO}_{2}$ (Fig. 2) these samples deviate from the other groups towards compositions similar to the andesites of Matthew and Hunter Islands (Maillet et al., 1986). Highly magnesian olivine (up to $\mathrm{Fo}_{93}$ ) and pyroxene phenocrysts ( $\mathrm{mg} \#=90$ ), often showing reverse zoning, and a wide compositional range of resorbed plagioclase phenocrysts suggest a complex evolutionary history for these samples.

\section{Sodic Rhyolites}

Ten glasses from four dredge stations are low-K rhyolites $(E w a r t, 1979)$ with $0.7-$ $0.2 \% \mathrm{MgO}$ and $69.8-74.4 \% \mathrm{SiO}_{2} . \mathrm{Na}_{2} \mathrm{O}$ is high but quite variable, ranging from $4.2-6.4 \%$ whereas $\mathrm{K}_{2} \mathrm{O}$ varies from $0.85-1.55 \%$. Further work is required to establish the relationships, if any, between the rhyolites and the other lithochemical groups. The rhyolites are found together with island arc tholeiites (Station 86 and 
88), boninites (Station 84 and 88), and at station 108, and could therefore represent highly fractionated endmembers of any of these groups.

\section{Olivine Compositions and Olivine-Spinel Pairs}

All glass-defined compositional groups, except for the rhyolites, contain olivinephyric samples, and twenty-eight samples were chosen for analysis of olivines and olivine-spinel pairs. For nine of those samples, no glasses were present so either glass inclusions in olivine or our unpublished wholerock analyses were used to group them. The range in Fo content in each group is shown in Fig. 3 and representative olivine-spinel pairs are given in Table 3. Compositional relations of olivine-spinel pairs for each group are presented in Fig. 4.

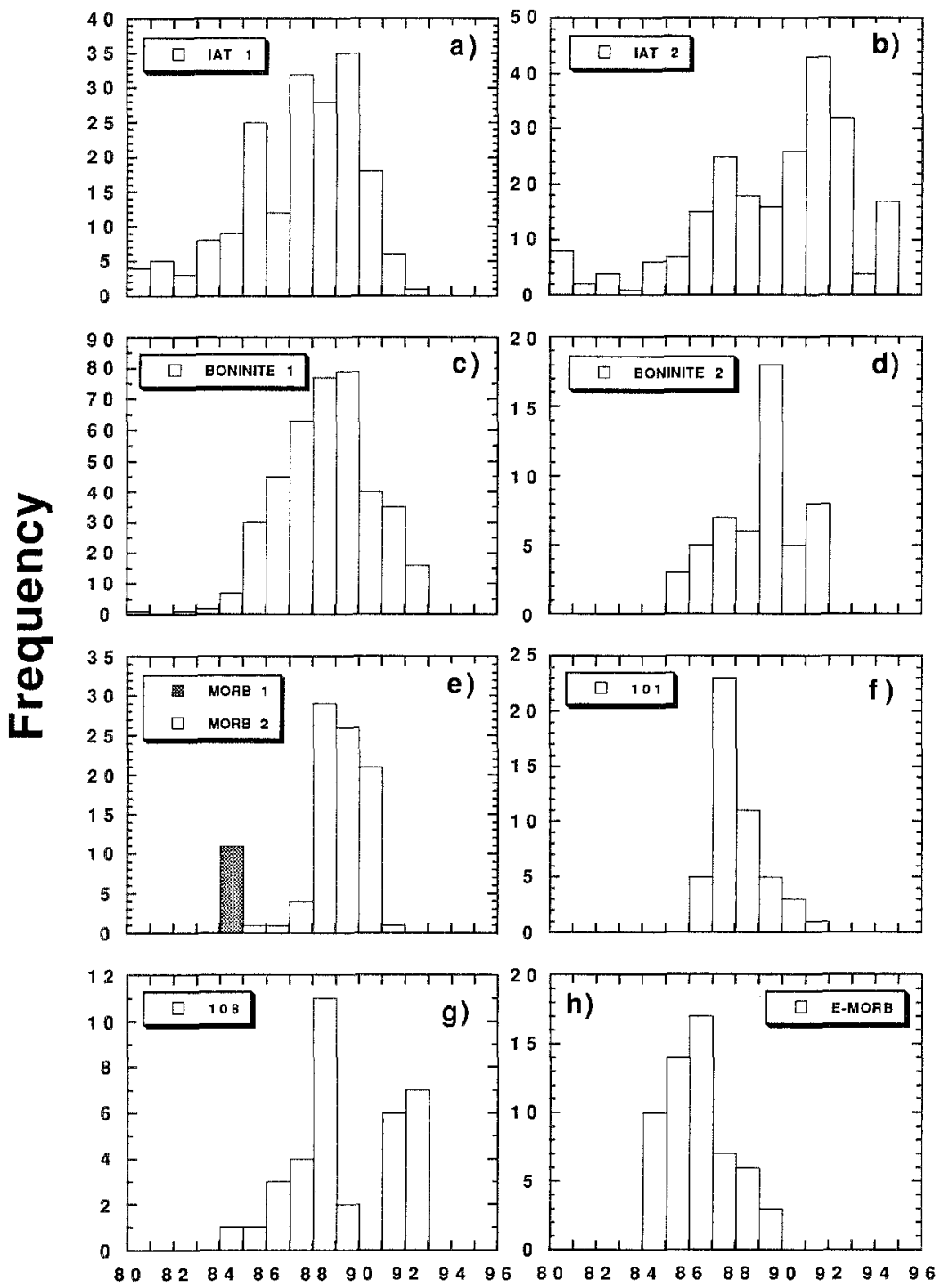

Fig. 3. Histograms showing Fo-content of olivine phenocrysts in the compositional groups identified 
Primitive Island Arc and Oceanic Lavas

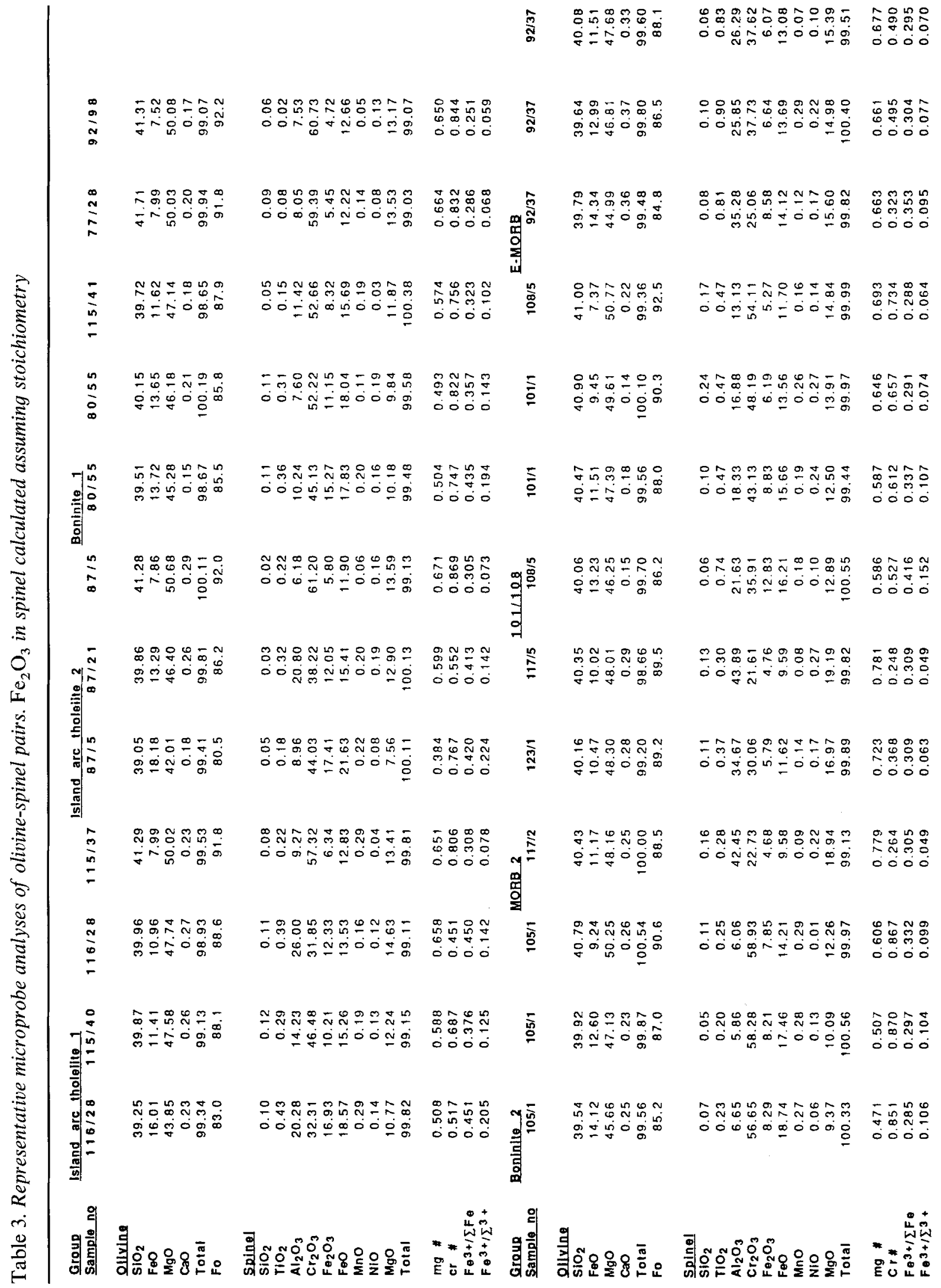



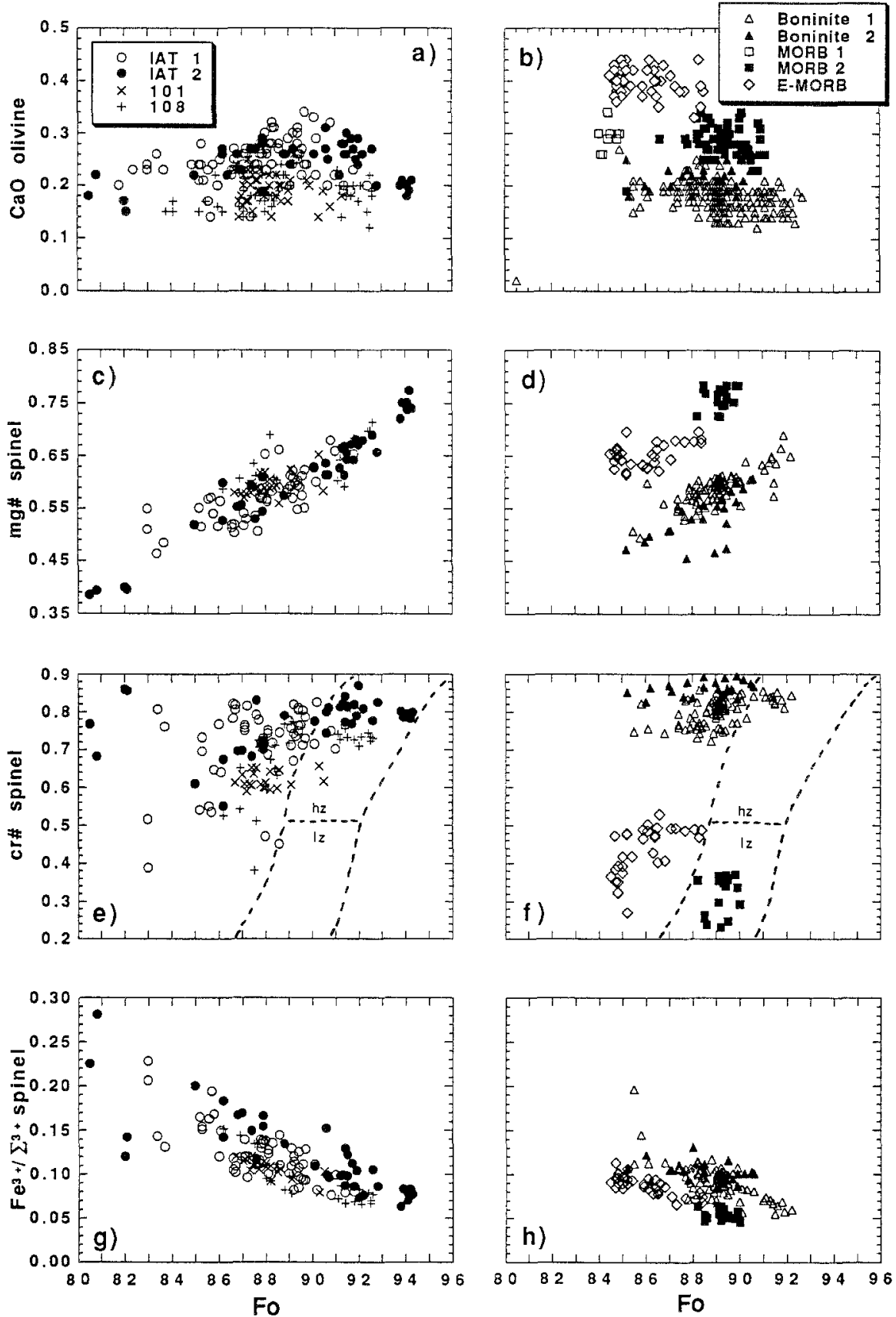

\section{Island Arc Tholeiites}

Olivine phenocrysts in the IAT range from $\mathrm{Fo}_{94.3-80}$ (Fig. 3a, b). Most samples show variations of 4-5 Fo units, except for sample $115 / 3$ that covers the range from $\mathrm{Fo}_{94.3-82} . \mathrm{CaO}$ contents in olivine vary from $0.15-0.34 \%$ with maximum values around $\mathrm{Fo}_{90}$, where clinopyroxene joins olivine as a liquidus phase (Fig. $\left.4 \mathrm{a}\right)$.

Most spinels have $\mathrm{Mg} /\left(\mathrm{Mg}+\mathrm{Fe}^{2+}\right)$ values (herein $\left.\mathrm{mg} \#\right)$ and $\mathrm{Cr} /(\mathrm{Cr}+\mathrm{Al}$ ) values (herein cr \#) higher than 0.5 (Fig. 4c, e, i), with only a few spinels in the least 

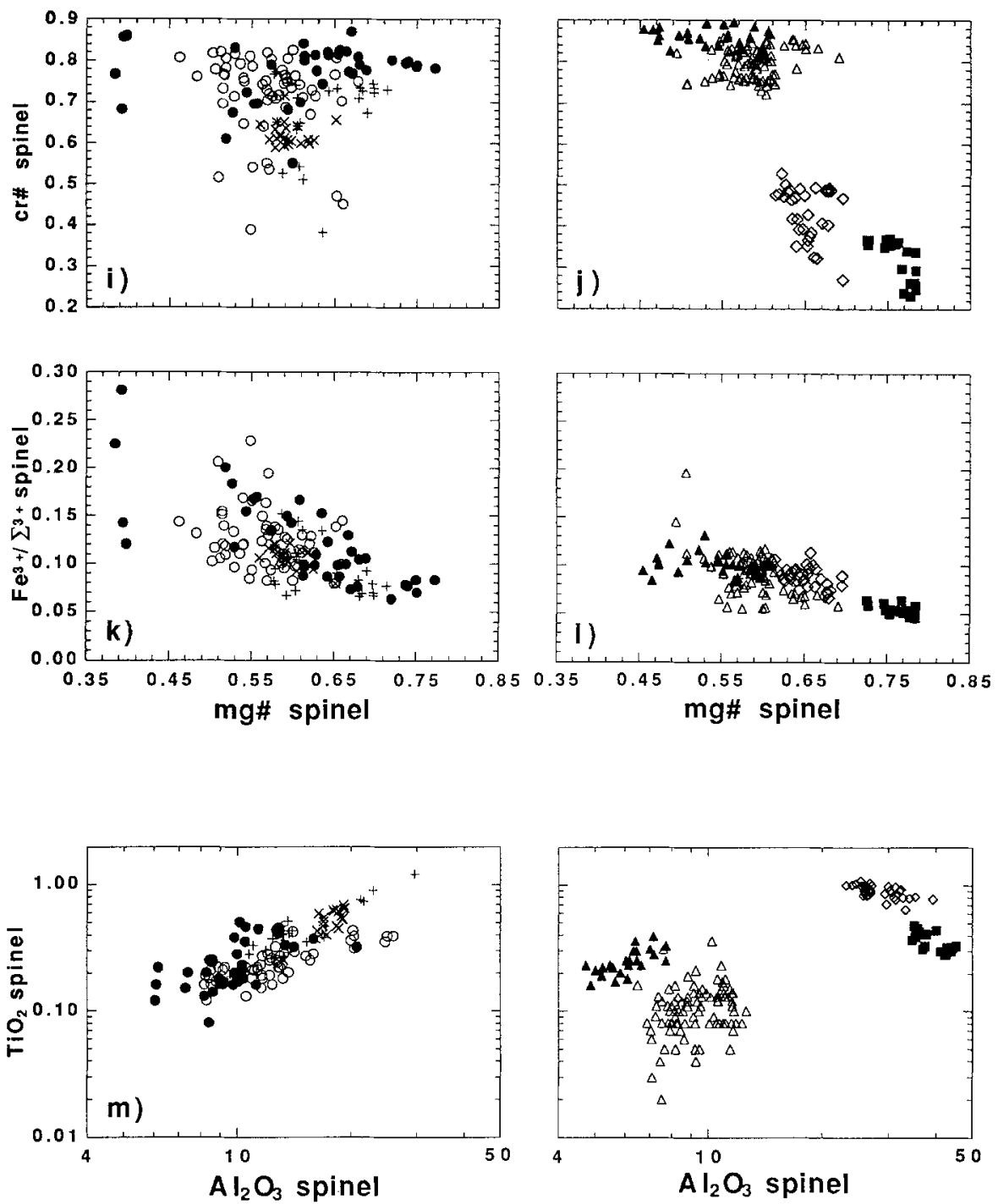

Fig 4. Compositional variations of olivine phenocrysts and spinel inclusions. a-b. Focontent in olivine vs. $\mathrm{CaO}$ in olivine. $\mathrm{c}-\mathrm{d}$. Fo vs $\mathrm{mg} \#$ of spinel. e-f. Fo vs $\mathrm{cr} \#$ of spinel, dashed lines show the mantle array from Arai (1987); $\mathrm{l}=$ spinel lherzolite; $\mathrm{hz}=$ spinel harzburgite. $\mathrm{g}-\mathrm{h}$. Fo vs $\mathrm{Fe}^{3+} /\left(\mathrm{Fe}^{3+}+\mathrm{Al}+\mathrm{Cr}\right)$ in spinel. $\mathrm{i}-\mathrm{j}$. $\mathrm{mg} \#$ vs cr \# in spinel. $\mathrm{k}-\mathrm{l}$. $\mathrm{mg} \#$ vs $\mathrm{Fe}^{3+} /\left(\mathrm{Fe}^{3+}+\mathrm{Al}+\mathrm{Cr}\right)$ in spinel. $\mathrm{m}-\mathrm{n} . \mathrm{Al}_{2} \mathrm{O}_{3}$ vs $\mathrm{TiO}_{2}$ in spinel. See text for discussion

forsteritic olivines having mg \# $<0.5$ (Fig. 4c). In IAT1, no spinels were found in olivines with Fo content lower than 83 , but IAT2 have spinels in olivines down to $\mathrm{Fo}_{80}$. A few spinels with $\mathrm{cr} \#<0.5$ are also present in some samples (Fig. $4 \mathrm{e}, \mathrm{i}$ ), mostly in sample $116 / 28$.

$\mathrm{TiO}_{2}$ contents of the spinels vary from $0.08-0.40 \%$ and $\mathrm{Al}_{2} \mathrm{O}_{3}$ varies from $5-26 \%$ (Fig. $4 \mathrm{~m}$ ). There is an overlap between IAT1 and IAT2 spinel compositions, but IAT2 spinels tend to have higher $\mathrm{TiO}_{2}$ contents (Fig. 4m) and higher $\mathrm{cr} \#$ (Fig. 4e, i), and to be more oxidized than IAT1 spinels (Fig. 4g, k). 
Boninites

Olivine compositions in the boninites vary from $\mathrm{Fo}_{93-80}$ (Fig. 3c, d) and they have lower $\mathrm{CaO}$ contents than IAT olivines, mainly from $0.10-0.25 \% \mathrm{CaO}$ (Fig. 4b). Coexisting spinels always have cr\# $>0.70$ (Fig. 4f) and there is no systematic change in cr \# with falling $\mathrm{mg}$ \# (Fig. 4j). BON2 spinels are generally distinct from those in $\mathrm{BON} 1$ by their lower $\mathrm{Al}_{2} \mathrm{O}_{3}$ and higher $\mathrm{TiO}_{2}$ contents (Fig $4 \mathrm{n}$ ), higher $\mathrm{cr} \#$ (Fig. 4f, j) and higher $\mathrm{Fe}^{3+}$ (Fig. 4h, l).

\section{Mid-Ocean Ridge Basalts}

Olivine in the MORB samples ranges from $\mathrm{Fo}_{91.1-84}(\mathrm{Fig} \mathrm{3e})$ with $\mathrm{CaO}$ contents from $0.23-0.34 \%$ (Fig. 4b). Most MORB samples are aphyric, and only one sample from MORB1 has olivine phenocrysts $\left(<1 \%, \mathrm{Fo}_{85-84}\right)$, but these lack spinel inclusions. In MORB2 samples, spinel inclusions were only found in olivine within the compositonal range $\mathrm{Fo}_{90-88}$. These spinels all have $\mathrm{mg} \#>0.72$ and $\mathrm{cr} \#<0.37$ (Fig. $4 \mathrm{~d}, \mathrm{f}, \mathrm{j}$ ) and $\mathrm{mg}$ \# is systematically higher than in spinel included in olivine of similar Fo content in both IAT and boninite samples (Fig 4c, d). $\mathrm{Fe}^{3+}$ contents are lower in MORB spinels than in all the other groups (Fig. $4 \mathrm{~g}, \mathrm{~h}$ ).

\section{Enriched Mid-Ocean Ridge Basalt}

Samples from station 73 are all aphyric so sample $92 / 37$ was chosen, on the basis of wholerock composition, to represent this group. Olivine vary from $\mathrm{Fo}_{90-84}$ (Fig. $3 \mathrm{~h}$ ) and have higher $\mathrm{CaO}$ contents $(0.33-0.44 \%)$ than olivine from the other groups (Fig. 4b). As for MORB spinels, E-MORB spinels have high mg \# (Fig. 4c, d) and low $\mathrm{Fe}^{3+}$ (Fig. 4g, h) compared to spinel in olivine of similar Fo content in IAT and boninite samples. cr \# is relatively low (0.25-0.55), although not as low as in MORB spinel (Fig. 4f, j).

\section{Stations 101 and 108}

Olivine compositions in samples from station 108 vary from $\mathrm{Fo}_{93-84}$ (Fig. 3g) and $\mathrm{CaO}$ contents of olivine are low $(0.11-0.25 \%)$, similar to those in the boninites (Fig. 4a) and in olivine from the andesites of Matthew and Hunter Island (Maillet et al., 1986). Olivines show a bimodal distribution, with no olivine between $\mathrm{Fo}_{89.1}$ and $\mathrm{Fo}_{91} \cdot \mathrm{Al}_{2} \mathrm{O}_{3}$ and $\mathrm{TiO}_{2}$ contents in spinels vary from levels similar to spinel in the IAT, with few spinels having higher $\mathrm{Al}_{2} \mathrm{O}_{3}$ and $\mathrm{TiO}_{2}$ contents, similar to those of the E-MORB spinels (Fig. 4m, n).

Olivine compositions in sample 101/1 vary from $\mathrm{Fo}_{92-86}$ and their $\mathrm{CaO}$ contents are similar to olivines in andesites from station 108. Spinels fall on the same trend as spinels from station 108 but show a more restricted compositional range (Fig. 4).

\section{Discussion}

\section{Primitive Boninite and Island Arc Tholeite Glasses}

Primitive basalts are rare in island arc settings, where basaltic andesites and more evolved compositions predominate (e.g. Ewart, 1976). Where primitive arc magmas 
do occur, in the Vanuatu arc for instance, (Gorton, 1977; Dupuy et al., 1982; Barsdell and Berry, 1990), they are generally subaerial, highly porphyritic and lack quenched glassy rims. Most analyses reported are of wholerock samples (occasionally with groundmass separates also analyzed, e.g. Barsdell 1988) that do not necessarily represent liquid compositions. It is, therefore, particularly significant to find glasses from suites of primitive to evolved island arc tholeiites and boninites.

Crawford et al. (1989) predicted that this part of the NFB, where the propagating spreading centre supplies the heat necessary to melt the cold, hydrated sub-arc(?) mantle at shallow levels, would be a likely scenario for boninite magmatism. The dredged BON 2 compositions represent the most refractory melt composition in this area. This may represent either magmas generated from different degrees of melting of a "damp" refractory mantle source or from multi-stage melting of a mantle source becoming more and more refractory.

\section{Back Arc Basin Basalt Versus MORB}

Based on major elements, trace elements and isotopes, Johnson and Sinton (1990) recognized three different basaltic magma types in the NFB, N-MORB, BABB and alkali-enriched basalt. They suggested that the BABB formed by hydrous melting of a MORB source mixed with a Samoan Shield ocean island basalt (OIB) source, and the alkali-enriched basalts by addition to the BABB source of a long term $\mathrm{Rb} / \mathrm{Sr}$-depleted, LILE-enriched component.

The MORB1 group has major element compositions similar to N-MORB, whereas MORB2 has higher $\mathrm{Al}_{2} \mathrm{O}_{3}$ and $\mathrm{Na}_{2} \mathrm{O}$ contents. When the $\mathrm{Al}_{2} \mathrm{O}_{3}$ and $\mathrm{Na}_{2} \mathrm{O}$ contents of the two MORB groups are compared with $\mathrm{Al}_{2} \mathrm{O}_{3}$ and $\mathrm{Na}_{2} \mathrm{O}$ contents of Type 1 (N-MORB) glasses from Johnson and Sinton (1990), plus additional "Type 1" glasses from Price et al., (1990); Eissen et al., (1991) and Sinton et al., (1991), there is a spectrum of compositions from N-MORB, as represented by the MORB 1 group, to more BABB-like compositions, represented by MORB2 (Fig. 5). This could represent either different pressures of melt segregation, with MORB1 derived via segregation at deeper levels than MORB2, or different melt fractions from an N-MORB mantle source. MORB1 and MORB2 magma types occur together at dredge station 117 , and similar occurrences of more than one type occur in some
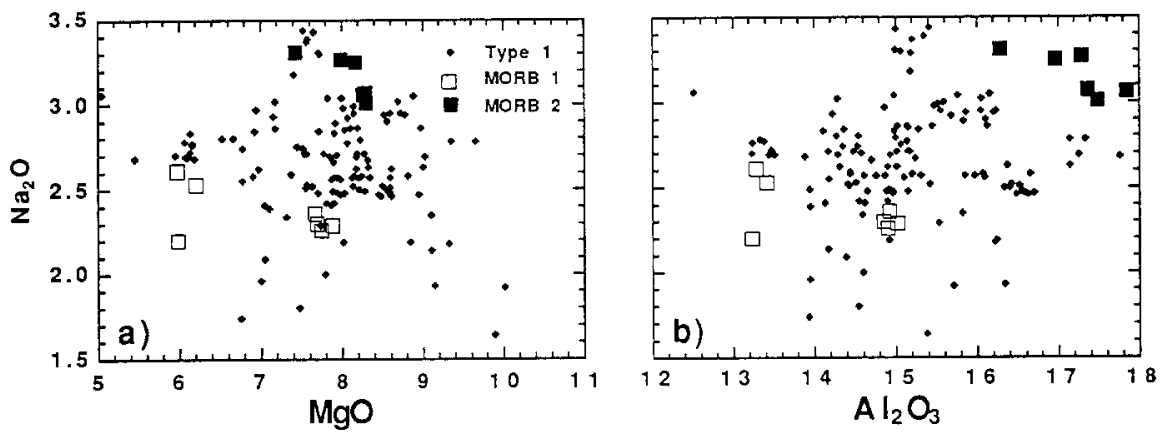

Fig. 5. $\mathrm{MgO}$ vs $\mathrm{Na}_{2} \mathrm{O}$ and $\mathrm{Al}_{2} \mathrm{O}_{3}$ vs $\mathrm{Na}_{2} \mathrm{O}$ variation diagrams for the two MORB groups compared to Type 1 glasses from the NFB (Johnson and Sinton, 1990; Price et al., 1990; Sinton et al., 1991; Eissen et al. 1991) 
dredge stations in the central and northern part of the NFB (e.g, Johnson and Sinton, 1990).

Our MORB1 and MORB2 suites correspond closely to the two MORB groups defined by Dmitriev et al.(1985) using a statistical analyses of a large Atlantic MORB glass database. These authors concluded that the two groups were derived from the same mantle composition, but at different pressures, one group in equilibrium with spinel lherzolite (MORB1) and the other with plagioclase lherzolite (MORB2).

\section{Enriched MORB}

Although ocean island basalt and E-MORB occur within near-zero age crust in the northern and central part of the NFB (Johnson and Sinton, 1990; Price et al., 1990; Sinton et al., 1991), there are none recorded from the southern arm of the spreading centre that extends south from the NFB triple junction (Eissen et al., 1991). The presence of E-MORB in dredge hauls from south of the Hunter Ridge, just north of the HFZ, is therefore anomalous and puzzling.

Dredge station 73 is unambiguously located on old SFB crust, south of the HFZ. However, petrographically and compositionally similar basalts were dredged from stations 87 and 92, between the HFZ and the Hunter Ridge. These E-MORB from just north of the HFZ are more altered, and appear older than the associated dredged IAT basalts and dolerites. We suggest, therefore, that this slice of the southernmost NFB is, in fact, part of the SFB that was trapped as the trench fronting the Vanuatu arc propagated (or stepped) southwards from Anatom. Alternatively, these E-MORB could represent rocks that were scraped off the SFB crust during oblique subduction during the last $5 \mathrm{Myr}$.

\section{Na-Rhyolites (Plagiogranites and Trondhjemites)}

High-Na, low-K silicic rocks have been described from various oceanic arc and backarc basin settings (e.g. Bryan, 1979; Ikeda and Yuasa, 1989; Ishizuka et al., 1990; Fryer et al., 1990; Hochstaedter et al., 1990a, b) and from ophiolites (e.g. Coleman and Peterman, 1975; Gerlach et al., 1981; Coish et al., 1982; Pearcy et al., 1990). Some controversy surrounds interpretation of their origin, and primary magma composition. Alternatives include fractional crystallization from a more basaltic parent (e.g. Coleman and Peterman, 1975), formation as a late stage immiscible liquid during fractional crystallization (e.g. Dixon and Rutherford, 1979), hydrous partial melting of basalts (e.g. Gerlach et al., 1981), and metasomatic alteration of low-K dacites (e.g. Pearcy et al., 1990).

The excellent state of preservation of these glassy felsic lavas from the Nesmeyanov dredged suite rules out an origin via $\mathrm{Na}$-metasomatism for these rocks. They show pronounced compositional similarities to high-Na rhyolites from the Sumisu Rift (Hochstaedter et al., 1990a). Hochstaedter et al. (1990b) showed that trace element (including REE) systematics of the Sumisu Rift Na-rhyolites supported their derivation from associated $\mathrm{BABB}$, although they could not conclude whether by fractionation or partial melting. Fryer et al. (1990) concluded on the basis of trace element compositions and $\mathrm{Nd}-\mathrm{Sr}$ isotopic data that the Sumisu Rift rhyolites are derived from the associated BABB by fractional crystallization. 
In contrast, rhyolites are not present together with MORB group lavas at any of the dredged stations in the NFB, but occur instead with IAT, boninites, and the andesites at station 108. These rhyolites are therefore likely to be related to one of these groups. Our unpublished trace element data show that there are at least two geochemically different groups of rhyolites, but further studies, including $\mathrm{Nd}-\mathrm{Sr}$ isotopic analyses in progress, are required to clarify the affinities and petrogenesis of these rocks.

\section{Olivine and Olivine-Spinel Pairs}

$\mathrm{CaO}$ is an important minor element in olivine and its concentration is believed to reflect both the physical and chemical environment of crystallization. Simkin and Smith (1970) showed that $\mathrm{CaO}$ in olivine in plutonic rocks is generally less than $0.1 \%$ whereas olivines in extrusive rocks have $\mathrm{CaO}$ higher than $0.1 \%$; they suggested that the depth (pressure) of crystallization had a strong influence on $\mathrm{CaO}$ concentration in olivine. Jurewicz and Watson (1988) showed experimentally that olivine $\mathrm{CaO}$ contents are dependent on the equilibrium melt composition (mainly $\mathrm{CaO}$ content), but are almost independent of temperature, $\mathrm{fO}_{2}$ and pressure, at least below $2.0 \mathrm{GPa}$. Besides $\mathrm{CaO}$, of the major elements, $\mathrm{SiO}_{2}$ is believed to have the greatest influence on the $\mathrm{CaO}$ concentration in olivine (Stormer, 1973).

Olivines in the E-MORB sample have the highest $\mathrm{CaO}$ contents while olivines in the boninites and andesites have the lowest $\mathrm{CaO}$ contents (Fig. $4 \mathrm{a}, \mathrm{b}$ ). This cannot be explained by differences in $\mathrm{CaO}$ contents between the melts because all the groups have similar $\mathrm{CaO}$ content at a given $\mathrm{MgO}$ (Fig. $2 \mathrm{i}, \mathrm{j}$ ). On the other hand, $\mathrm{SiO}_{2}$ content is very different between the groups, lowest in the E-MORB and highest in the boninites and andesites, supporting the implied strong influence of melt $\mathrm{SiO}_{2}$ on olivine $\mathrm{CaO}$ content.

All magmatic groups identified here include samples that have olivine compositions that are as, or more, magnesian than reported in the literature for similar magma series. For example, MORB2 have olivine as magnesian as $\mathrm{Fo}_{92}$ whereas Dmitriev et al. (1985) found no olivine more magnesian than $\mathrm{Fo}_{90}$ in samples with similar glass compositions. The most magnesian olivines $\left(\mathrm{Fo}_{94.3}\right)$ are found in IAT2 (Fig. 3), even though these glasses have the highest $\mathrm{FeO}^{*}$ at a given $\mathrm{MgO}$ content (Fig. $2 \mathrm{~g}, \mathrm{~h}$ ). Since the olivine-hosted spinels in these rocks have the highest $\mathrm{Fe}^{3+}$ values among the magmatic groups we have identified (Fig. 4k, 1), the olivine and spinel in the IAT2 magma probably crystallized under more oxidized conditions than the other magmatic groups.

All magma groups show a strong linear relationship between Fo content of olivine and $\mathrm{mg}$ \# of coexisting spinel (Fig. 4c, 4d), but at any given Fo content BON2 spinels have the lowest $\mathrm{mg} \#$ and MORB2 the highest. Most magmatic groups have a limited range in spinel compositions and in figure $4 \mathrm{n}$ spinels in the boninite, E-MORB and MORB suites form discrete, coherent groups. Spinels in the IAT and andesites, on the other hand, show more compositional spread and overlap with the boninite groups (Fig. $4 \mathrm{n}, \mathrm{m}$ ). The andesite spinel compositions form a mixing trend between either boninite or IAT compositions towards more fertile spinel compositions (eg. E-MORB), whereas IAT1 spinel compositions show a mixing trend towards the MORB spinel field, indicating that magma mixing probably played an 
important role in magma generation in this area. This will be tested by detailed trace element and isotopic studies in progress.

The cr \# of spinel is a useful indicator of the degree of melting, or extent of depletion, of the mantle source (Dick and Bullen, 1984) and in Figures 4e and f, cr \# is plotted against Fo-content of the host olivine. The mantle array of olivine-spinel systematics, defined by Arai (1987), from spinel lherzolites and spinel harzburgites is shown for comparison. Spinels in the boninites have the highest $\mathrm{cr} \#$, indicating the most refractory source composition for these magmas, whereas the MORB have the lowest $\mathrm{cr}$ \# and presumably derive from the most fertile magma source. Spinels in primitive MORB generally have cr \# $<0.3$, but plagioclase cofractionation with olivine in typical MORB pushes spinel cr \# values into the range 0.4-0.6 (Sigurdsson and Schilling, 1976). This indicates either a more fertile lherzolitic mantle source or lower degree of melting for MORB2 spinel than for the E-MORB spinel. Spinels from the other groups suggest harzburgitic mantle sources. Spinels from all groups defined herein fall within or close to the mantle array, examplifying the primitive nature of these lavas.

\section{Conclusions}

Major element analyses of over 100 glasses from the southernmost part of the North Fiji Basin show that this area contains an exceptionally diverse spectrum of magma types. Nine magmatic groups are recognized, including primitive island arc tholeiites, boninites, MORB and E-MORB. Highly forsteritic olivine, often exceeding values previously reported for these magma series, confirm the near-primary nature of these samples.

Glasses of primitive island arc tholeiite composition are rarely reported, and trace element and isotopic studies of these rocks (in progress) should offer important constraints on magma genesis in young, primitive intra-oceanic areas, and clarify the relationships, if any, between arc tholeiites and high- $\mathrm{Ca}$ boninites. The discovery of boninites confirms a prediction that the juxtaposition of hot MORB upper mantle beneath the NFB spreading centre, and the sub-arc mantle beneath the Hunter Ridge, could produce boninitic magmas in this region (Crawford et al., 1989).

Primitive MORB, containing highly forsteritic olivine and high alumina spinels, were found not only in the North Fiji Basin proper, but also perhaps unexpectedly, south of the Hunter Ridge, in close proximity to both the island arc tholeiites and boninites. This probably confirms the tectonic scenario put forward by Maillet et al. (1989) in which the break in the Hunter Ridge in this area is interpreted to be a pull-apart structure due to southward propagation of the main North Fiji Basin spreading centre through the Hunter Ridge.

Extensive crystal fractionation from either island arc tholeiites or high-Ca boninites is the most likely scenario for generation of the Na-rhyolites, though other possibilities could not be ruled out. Detailed investigations of the dredged rocks from this area are currently underway and will be reported at a later date.

\section{Acknowledgements}

We thank the Captain and crew of R/V Academican A. Nesmeyanov as well as the onboard scientific team and the Chief Scientist, I. K. Puschin. 
We also thank L. V. Danyushevsky for analysing some of the glasses, W. Jablonski for technical assistance and $M$. Kamenetsky for assistance with sample preparation. J. Sinton and $P$. Maillet provided useful reviews, and M. Monzier is thanked for providing a preprint of his work on submarine volcanoes from southern Vanuatu.

\section{References}

Arai $S$ (1987) An estimation of the least depleted spinel peridotite on the basis of olivinespinel mantle array. $\mathrm{N} \mathrm{Jb}$ Miner Mh 8: 347-354

Auzende JM, Eissen JP, Lafoy Y, Gente P, Charlou JL (1988a) Seafloor spreading in the North Fiji Basin (Southwest Pacific). Tectonophysics 146: 317-351

Auzende JM, Lafoy Y, Marsset B (1988b) Recent geodynamic evolution of the North Fiji Basin (southwest Pacific). Geology 16: 925-989

Barsdell $M$ (1988) Petrology and petrogenesis of clinopyroxene-rich tholeiitic lavas, Merelava volcano, Vanuatu. J Petrol 29: 927-964

Barsdell M, Berry RF (1990) The petrology and geochemistry of Western Epi. J Petrol 31: $747-777$

Bryan $W B$ (1979) Low-K dacites from the Tonga-Kermadec island arc: petrography, chemistry, and petrogenesis. In: Barker $F(\mathrm{ed})$ Trondhjemites, dacites and related volcanic rocks. Elsevier, Amsterdam, pp 581-601

Coish RA, Hickey R, Frey FA (1982) Rare earth element geochemistry of the Betts Cove ophiolite, Newfoundland: complexities in ophiolite formation. Geochim Cosmochim Acta 46: 2117-2134

Coleman RG, Peterman ZE (1975) Oceanic plagiogranite. J Geophys Res 80: 1099-1108

Crawford AJ, Falloon TJ, Green DH (1989) Classification, petrogenesis and tectonic setting of boninites. In: Crawford AJ, (ed) Boninites and related rocks. Unwin Hyman, London, pp 1-49

Dick $H J B$, Bullen $T$ (1984) Chromian spinel as a petrogenetic indicator in abyssal and alpine-type peridotites and spatially associated lavas. Contrib Mineral Petrol 86: 54-76

Dixon S, Rutherford MJ (1979) Plagiogranites as late stage immiscible liquids in ophiolite and mid-ocean ridge suites: an experimental study. Earth Planet Sci Lett 45: 45-60

Dmitriev LV, Sobolev AV, Suschevskaya NM, Zapunny SA (1985) Abyssal glasses, petrologic mapping of the oceanic floor and "geochemical leg" 82. In: Bougault H, Cande SC et al (eds) Init Repts, DSDP, 82: Washington (U.S. Govt Printing Office), 509-518

Dubois $J$, Launay $J$, Recy $J$ (1977) New Hebrides trench: subduction rate from associated lithospheric bulge. Can J Earth Sci 14: 250-255

Dupuy C, Dostal J, Marcelot G, Bougault H, Joron JL, Treuil M (1982) Geochemistry of basalts from central and southern New Hebrides arc: implication for their source rock composition. Earth Planet Sci Lett 60: 207-225

Eissen J-P, Lefévre C, Maillet P, Morvan G, Nohara M (1991) Petrology and geochemistry of the central North Fiji Basin spreading center (Southwest Pacific) between $16^{\circ} \mathrm{S}$ and 22 S. Marine Geology 98: 201-239

Ewart A (1976) Mineralogy and chemistry of modern orogenic lavas-some statistics and implications. Earth Planet Sci Lett 31: 417-432

Ewart $A$ (1979) A review of the mineralogy and chemistry of Tertiary-Recent dacitic, rhyolitic, and related salic volcanic rocks. In: Barker F (ed) Trondhjemites, dacites and related volcanic rocks. Elsevier, Amsterdam, pp 13-21

Fryer P, Sinton JM, Philpotts JA (1981) Basaltic glasses from the Mariana trough. In: Hussong DM, Uyeda S et al, (eds) Init Repts DSDP 60; Washington (U.S. Govt. Printing Office) 601-609 
Fryer $P$, Taylor $B$, Langmuir $C H$, Hochstaedter $A G$ (1990) Petrology and geochemistry of lavas from Sumisu and Torishima backarc rifts. Earth Planet Sci Lett 100: 161-178

Gerlach DC, Leeman WP, Avé Lallemant $H G$ (1981) Petrology and geochemistry of plagiogranite in the Canyon Mountain Ophiolite, Oregon. Contrib Mineral Petrol 77: 82-92

Gorton MP (1977) The geochemistry and origin of Quaternary volcanism in the New Hebrides. Geochim Cosmochim Acta 41: 1257-1270

Hamburger MW, Isacks BL (1987) Deep earthquakes in the South Pacific: A tectonic interpretation. J Geophys Res 92: 13841-13854

Hochstaedter AG, Gill JB, Kusakabe M, Newman S, Pringle M, Taylor B, Fryer P (1990a) Volcanism in the Sumisu Rift, I. Major element, volatile, and stable isotope geochemistry. Earth Planet Sci Lett 100: 179-194

Hochstaedter AG, Gill JG, Morris JD (1990b) Volcanism in the Sumisu Rift, II. Subduction and non-subduction related components. Earth Planet Sci Lett 100: 195-209

Ikeda Y, Yuasa $M$ (1989) Volcanism in nascent back-arc basin behind the Shichito Ridge and adjacent areas in the Izu-Ogazawara arc, northwest Pacific: evidence for mixing between E-type MORB and island arc magmas at the initiation of back-arc rifting. Contrib Mineral Petrol 101: 377-393

Ishizuka $H$, Kawanobe $Y$, Sakai $H$ (1990) Petrology and geochemistry of volcanic rocks dredged from the Okinawa Trough, an active back arc basin Geochemical Journal 24: $75-92$

Jakes $P$, Gill $J(1970)$ Rare earth elements and the island arc tholeiitic series. Earth Planet Sci Lett 9: 17-28

Jarosewich EJ, Nelen $J A$, Norberg $J A$ (1980) Reference samples for electron microprobe analysis. Geostandards Newsletter 4: 43-47

Johnson KTM, Sinton JM (1990) Petrology, tectonic setting, and the formation of back-arc basin basalts in the North Fiji Basin. Geol Jb D92: 517-545

Jurewicz AJG, Watson EB (1988) Cations in olivine, Part 1: calcium partitioning and calcium-magnesium distribution between olivines and coexisting melts, with petrologic applications. Contrib Mineral Petrol 99: 176-185

Lavrentev YG, Pospelova LN, Sobolev NV (1974) Rock-forming mineral compositions determination by X-ray microanalysis. Zavodskaya Laboratoria 40: 657-666 (in Russian)

Maillet $P$, Monzier M, Lefevre $C$ (1986) Petrology of Matthew and Hunter volcanoes, south New Hebrides island arc (Southwest Pacific). J Volcanol Geotherm Res 30: 1-27

Maillet P, Monzier M, Eissen J-P, Louat R (1989) Geodynamics of an arc-ridge junction: the case of the New Hebrides Arc/North Fiji Basin. Tectonophysics 165: 251-268

Miyashiro A (1974) Volcanic rock series in island arcs and active continental margin. Am. Journal Sci. 274: 321-355

Monzier M, Maillet P, Foyo Herrera J, Louat R, Missegue F, Pontoise B (1984) The termination of the southern New Hebrides subduction zone (southwestern Pacific). Tectonophysics 101: 177-184

Monzier M, Danyushevsky LV, Crawford AJ, Bellon H, Cotten J (1992) High-Mg andesites from the southern termination of the New Hebrides island arc (SW Pacific). J Volcanol Geotherm Res (submitted)

Pearcy LG, DeBari SM, Sleep NH (1990) Mass balance calculations for two sections of island arc crust and implication for the formation of continents. Earth Planet Sci Lett 96: $427-442$

Price RC, Johnson LE, Crawford AJ (1990) Basalts of the North Fiji Basin: the generation of back arc basin magmas by mixing of depleted and enriched mantle sources. Contrib Mineral Petrol 105: 106-121

Sigurdsson H, Schilling JG (1976) Spinels in Mid-Atlantic Ridge basalts: chemistry and occurrence. Earth Planet Sci Lett 29: 7-20 
Simkin T, Smith JV (1970) Minor-element distribution in olivines. J Geology 78: 304-325

Sinton JM, Johnson KTM, Price RC, Staudigel H, Zindler A (1991) Petrology and geochemistry of submarine lavas from the Lau and North Fiji back-arc basins. In: Kroenke $L W$, Eade $J V$ (eds) Basin formation ridge crest processes, and metallogenesis in the North Fiji Basin. (Circum-Pacific Council for Energy and Mineral Resources, Earth Science series, 3) 12: $155-177$

Stormer JC (1973) Calcium zoning in olivine and its relationship to silica activity and pressure. Geochim Cosmochim Acta 37: 1815-1821

Sun SS, McDonough WF (1989) Chemical and isotopic systematics of oceanic basalts: implications for mantle composition and processes. In: Saunders $A D$, Norry $M J$ (eds) Magmatism in the ocean basins. Geological Society Special Pub 42: 313-345

Authors' addresses: I. A. Sigurdsson, Dr. V. S. Kamenetsky and Dr. A. J. Crawford, Department of Geology, University of Tasmania, GPO Box 252C, Hobart, 7001, Tasmania, Australia; Dr. V. S. Kamenetsky and Dr. S. K. Zlobin, Vernadsky Institute of Geochemistry, Russian Academy of Sciences, Moscow 117975, Russia; Dr. S. M. Eggins, Research School of Earth Sciences, Australian National University, GPO Box 4, Canberra 2601, Australia. 